\title{
Simultaneous canine distemper encephalitis and canine parvovirus infection with distemper-associated cardiac necrosis in a pup
}

\author{
Infecção simultânea por vírus da cinomose e da parvovirose associada à necrose \\ cardíaca em um canino
}

\author{
Selwyn Arlington Headley ${ }^{1}$ Taís Berelli Saito $^{2}$
}

\section{- CASE REPORT -}

\section{ABSTRACT}

Simultaneous infection of canine distemper virus and canine parvovirus associated with distemper myocardial degeneration and necrosis is described in a pup. The dog demonstrated myoclonus, nystagmus, enamel hypoplasia, abdominal pustules, and bilateral corneal ulceration clinically. Demyelinating encephalitis, myocardial degeneration and necrosis with mineralization, and necrosis, hemorrhage and fusion of intestinal villi were observed. The lesions observed in this dog are characteristic of a dual infection of canine distemper virus and canine parvovirus.

Key words: canine distemper virus, canine parvovirus, encephalitis, cardiac necrosis.

\section{RESUMO}

Descreve-se a infecção simultânea de cinomose e parvovirose associada à degeneração e necrose do miocárdio em um cão. Clinicamente, o cão apresentou mioclonias, nistagmo, hipoplasia do esmalte dentário, pústulas abdominais e ulceração bilateral da córnea. Foram observadas encefalite desmielinzante, degeneração e necrose do miocárdio com mineralização, e necrose, hemorragia e fusão das vilosidades intestinais. As lesões observadas neste cão são características com uma infecção pelos vírus da cinomose e da parvovirose.

Palavras-chave: cinomose, parvovirose canina, encefalite, necrose cardíaca.

\section{INTRODUCTION}

Canine distemper virus (CDV) produces acute to chronic demyelinating encephalitis in dogs and other carnivores (DUNGWORTH, 1993; JONES et al., 1997). CDV is the most ubiquitous and important disease of the dog (DUNGWORTH, 1993), and is the principal infectious agent responsible for the death of dogs maintained in some veterinary teaching hospitals in Brazil (HEADLEY \& GRAÇA, 2000).

In acute canine distemper encephalitis, CDV produces immunosuppression (KRAKOWKA et al., 1980) by acting directly on $\mathrm{CD}^{+}$cells (WÜNSCHMANN et al., 2000). Therefore, dogs infected with CDV are more susceptible to develop secondary fungal (FUKUSHIMA \& HELMAN, 1984), parasitic (CAMPBELL et al., 1955; TIPOLD et al., 1992), bacterial (HEADLEY et al., 1999), or other viral (KOBAYASHI et al., 1993) infections. Canine parvovirus (CPV) infection has been known to induce an immunomodulating effect on dogs administered polyvalent vaccine (KRAKOWKA et al., 1982). CDV and CPV have been associated with cardiac necrosis in pups. It was demonstrated that the salient difference between these two cardiac viral-associated infections

\footnotetext{
${ }^{1}$ Médico Veterinário, MSc, Professor do Departamento de Patologia Veterinária, Curso de Medicina Veterinária, Centro Universitário de Maringá, (CESUMAR), Jd. Aclimação, 87050-390, Maringá, PR. E-mail: headleysa@cesumar.br. Autor para correspondência. ${ }^{2}$ Médico Veterinário, MSc, Professora do Departamento de Clínica Médica de Pequenos Animais, CESUMAR.
} 
is a marked absence of mineralization of cardiac fibers in CPV, with severe mineralization in cases of distemper encephalitis (HIGGINS et al., 1981). A recent MedLine review did not reveal reports of dual canine parvovirus and canine distemper infections associated with cardiac necrosis. This report describes the simultaneous infection of CDV and CPV with $\mathrm{CDV}$-associated cardiac necrosis in a pup.

\section{CASE REPORT}

The dog in question was a four-month-old, intact male, English Cocker Spaniel that had reportedly received a single dose of a polyvalent vaccine. Three days after receiving the dose the dog reportedly demonstrated apathy, acute fever, anorexia, myoclonus in the right anterior limb, abdominal pustules, and a mild transient diarrhea. The dog was then referred to the Veterinary Teaching Hospital (VTH) for clinical evaluation where a combination therapy of antibiotics, antioxidant, and corticoids was administered and the animal was sent home. Ten days after the initial episode the dog was reexamined at the VTH without any great improvement. At this time elevated body temperature, severe dehydration, respiratory distress, convulsions, myoclonus of the right anterior limb, nystagmus, and bilateral ulceration of the cornea were observed. Euthanasia was carried out and a routine necropsy examination was performed. Tissues selected for light microscopic examination were fixed in $10 \%$ formalin solution, embedded in paraffin, sectioned at $4 \mu \mathrm{m}$, and stained with hematoxylin and eosin (HE).

\section{RESULTS AND DISCUSSION}

At necropsy the dog was slightly emaciated, dehydrated with severe enamel hypoplasia of developing teeth and bilateral corneal ulceration. The tonsils were severely hemorrhagic and enlarged. Regional lymph nodes were noticeably enlarged with marked loss of cortical and medullar differentiation. Pale irregular whitish streaks were observed on the myocardium. The serous surface of the intestine was finely granular; there was moderate multifocal hemorrhages and severe multifocal depression of the center of Payer's patches. The lungs were congested and slightly hemorrhagic.

Microscopically, there was severe multifocal necrosis of the epithelium of the tonsils, marked hydropic degeneration of epithelial cells and severe depletion of the lymphoid tissue; few intracytoplasmic eosinophilic inclusion bodies were observed in epithelial cells. Marked cortical depletion of lymphoid tissue was also observed in the lymph nodes examined. Severe, multifocal, subacute demyelinating encephalitis was prominent in the cerebellum. Subacute demyelinating encephalitis was characterized by tiny perivascular cuffs formed by one or two layers of mononuclear cells, discrete astrocytic proliferation, and moderate astrocytosis with abundant intranuclear inclusion bodies in astrocytes. In the heart, there was multifocal myocardial degeneration and necrosis associated with mineralization of cardiac fibers and intracytoplasmic eosinophilic inclusion bodies in myocytes. Viral inclusion bodies were more abundant adjacent to and within the mineralized areas. Intestinal lesions of canine parvovirus infection were characterized by severe necrosis of epithelial cells and intestinal crypts associated with marked fusion and atrophy of villi.

The gross and microscopic alterations observed in this pup are characteristic of a dual infection of canine distemper virus and canine parvovirus (DUBIELZIG et al., 1981; HIGGINS et al., 1981; DUNGWORTH, 1993; JONES et al., 1997). Enamel hypoplasia observed in this pup is a direct effect of CDV on the ameloblasts during teeth development (DUBIELZIG et al., 1981). The abdominal pustules described in the present report are cutaneous manifestations of CDV complicated with staphylococci and streptococci infections (DUNGWORTH, 1993). Myoclonus, nystagmus, and convulsions observed in this case are common neurological manifestations of CDV infection (TIPOLD et al., 1992; DUNGWORTH, 1993; JONES et al., 1997). Myoclonus is considered highly characteristic (TIPOLD et al., 1992), or even pathognomonic (DUNGWORTH, 1993) for CDV infection.

Myocardial degeneration induced by CDV is one of the most outstanding lesions observed in this pup. Myocardial degeneration and necrosis in the dog has also been associated with CPV (JONES et al., 1997), Toxoplasma gondii (CAMPBELL et al., 1955), and nutritional deficiencies (VAN VLEET \& FERRANS, 1995). However, microscopically these lesions are not consistent with the myocardial alterations observed in this pup. $\mathrm{CDV}$-associated myocardial degeneration and necrosis occurs naturally in the suckling dog (DUNGWORTH, 1993), and have been induced experimentally in dogs (HIGGINS et al., 1981). The alterations observed in the present case are consistent with those described in experimental induced distemper myocardial necrosis (HIGGINS et al., 1981). The intestinal lesions observed in this pup are characteristic of CPV infection (JONES et al., 1997). Interesting in this case, parvovirus was not clinically suspected and 
consequently no treatment was designed to combat this fatal infection.

This case reinforces the idea that immature and inadequately vaccinated dogs are highly susceptible to CDV infection establishing a definite relationship between age and susceptibility to infection (KRAKOWKA \& KOESTNER, 1976; HEADLEY et al., 2001). CDV has been shown to induce depopulation of $\mathrm{CD}^{+}$cells in dogs with acute distemper encephalitis (WÜNSCHMANN et al., 2000), while CPV has been associated with vaccination failures in dogs (KRAKOWKA et al., 1982). These factors may explain why this dog did not respond adequately to the vaccine received, considering that $\mathrm{CPV}$ infection may have occurred before CDV infection.

\section{REFERENCES}

CAMPBELL, R.S.F.; MARTIN, W.B.; GORDON, E.D. Toxoplasmosis as a complication of canine distemper. Veterinary Record, v.48, p.708-712, 1955.

DUNGWORTH, D.L. The respiratory system. In: JUBB, K.V.F.; KENNEDY, P.C.; PALMER, N. Pathology of domestic animals. 4. ed. San Diego : Academic, 1993. V.2, p.617-624.

DUBIELZIG, R.R.; HIGGINS, R.J.; KRAKOWKA, S. Lesions of the enamel organ of developing dog teeth following experimental inoculation of gnotobiotic dogs with canine distemper virus. Veterinary Pathology, v.18, p.684-689, 1981.

FUKUSHIMA, K.; HELMAN, R.G. Cryptosporidiosis in a pup with distemper. Veterinary Pathology, v.21, p.247-248, 1984.

HEADLEY, S.A. et al. Canine distemper virus infection with secondary Bordetella bronchiseptica pneumonia in dogs. Ciência Rural, v.29, p.741-743, 1999.

HEADLEY, S.A.; GRAÇA, D.L. Canine distemper: epidemiological findings of 250 cases. Brazilian Journal of Veterinary Research and Animal Science, v.37, n.2, [Cited 4
Mar. 2002]. p.00-00, 2000. On line. Available from World Wide Web: http://www.scielo.br/scielo.php.

HEADLEY, S.A.; SOARES, I.C.; GRAÇA, D.L. Glial fibrillary acidic protein (GFAP)-immunoreactive astrocytes in dogs infected with canine distemper virus. Journal of Comparative Pathology, v.125, p.90-97, 2001.

HIGGINS, R.J. et al. Canine distemper virus-associated cardiac necrosis in the dog. Veterinary Pathology, v.18, p.472-486, 1981.

JONES, T.C.; HUNT, R.D.; KING, N.W. Diseases caused by parvoviruses. Diseases caused by morbilliviruses. Veterinary pathology. 6. ed. Baltimore : Lippincott Williams \& Wilkins, 1997. p.257-261. p.311-315.

KOBAYASHI, Y.; OCHIAI, K.; ITAKURA, C. Dual infection with canine distemper virus and infectious hepatitis virus (Canine Adenovirus Type I) in a dog. Journal of Veterinary Medical Science, v.55, p.699-701, 1993.

KRAKOWKA, S.; KOESTNER, A. Age-related susceptibility to infection with canine distemper virus in gnotobiotic dogs. The Journal of Infectious Diseases, v.134, p.629-632, 1976.

KRAKOWKA, S.; HIGGINS, R.J., KOESTNER, A. Canine distemper virus: review of structural modulations in lymphoid tissues. American Journal of Veterinary Research, v.41, p.284-292, 1980.

KRAKOWKA, S. et.al. Canine parvovirus infection potentates canine distemper virus encephalitis attributable to modified livevirus vaccine. Journal of the American Veterinary Medical Association, v.180, p.137-139, 1982.

TIPOLD, A.; VANDEVELDE, M.; JAGGY, A. Neurological manifestations of canine distemper infection. Journal of Small Animal Practice, v.33, p.466-470, 1992.

VAN VLEET, J.F.; FERRANS, V.J. Pathology of the cardiovascular system. In: CARLTON, W.W.; McGAVIN, M. D. Thomson's special veterinary pathology. 2. ed. St. Louis : Mosby, 1995. Cap.4, p.175-208.

WÜNSCHMANN, A.; KREMMER, E.; BAUMGÄRTNER, W. Phenotypical characterization of $\mathrm{T}$ and $\mathrm{B}$ cells areas in lymphoid tissues of dogs with spontaneous distemper. Veterinary Immunology and Immunopathology, v.73, p.83-98, 2000. 